The University of Utopia

By Robert M. Hutchins. (Chicago : University of Chicago Press ; London: Cambridge University Press, 1953.) 19s. net.

TN this brilliant sketch of the imaginary University I of Utopia, Dr. Robert M. Hutchins's avowed purpose is not so much to describe the educationa system of Utopia, of which that university forms the apex, as to depict the hazards to education in the United States and the means by which these hazards may be reduced or eliminated. Chief among them are those arising out of industrialization, specialization, philosophical diversity in relation to the formation of a community, and social and political conformity. These are discussed with wit and shrewdness in four successive chapters representing lectures delivered at the University of Chicago in the spring of 1953. He has returned to some of his criticism of the American universities in lectures on the idea of an American university delivered in Great Britain last autumn, but those lectures are likely to encourage his hearers to read this book.

Although the American university is the main target of his criticism and his fourth chapter in particular is as courageous and forthright a defence of academic freedom and responsibility as is to be found in Prof. Commager's recent book, with which it may be fittingly compared, the book abounds in common sense, in aphorisms, in hard thrusts and asides which will delight the British as much as the American reader. His characterization of the custodial system resulting from the infringement of academic independence as 'adolescent-sitting' may no more commend itself in some quarters than did a certain bishop's proposal to a Lambeth Conference to entitle a conference report on education "Childhood by Second-Childhood". The value of the book, however, does not lie in its occasional astringencies but in the clarity with which it lays bare the fundamental issues involved in deciding what are the functions of a university in the world to-day. The important questions are asked, the essential principles are stated and all concerned with the application of these principles in the expansion of university and technological education in Great Britain, or with the wider question of adult education and the defence of freedom, can read these pages with profit as well as pleasure.

R. BRIGHTMAN

\section{Physical Constants of Hydrocarbons}

Vol. 5: Paraffins, Olefins, Acetylenes and other Aliphatic Hydrocarbons. (Revised Values.) By Gustav Egloff. (Monograph Serits No. 78.) Pp. ix +524. (New York: Reinhold Publishing Cor poration ; London : Chapman and Hall, Ltd., 1953.) 160s. net.

THIS volume supplements the values for the melting points, boiling points, densities and refractive indices of paraffins, olefines, acetylenes and other aliphatic hydrocarbons which were collected in Vol. 1. Best values for the normal boiling points, densities and refractive indices of many compounds are also given. Corrections to Vol, 1 are listed with cross-references.

The general arrangement of the matter in the present volume is rather wasteful of space and is frequently not clear. For example, under melting points the symbol $a$ is used approximately two hundred times and is followed by the sentence "(a) This constant was given as a freezing point in the literature"; if it were necessary to make this distinction, it would have been simpler to put the symbol F.p. in the table. Moreover, confusion may arise because the symbol $a$ is used in the same section for other purposes ; for example, on p. 10 it means "This is a calculated value", while it has other meanings on pp. 228, 262 and 270. Further, since $a$ may have different meanings on the same page, it will be appreciated that there is room for improvement in the arrangement.

Some idiosyncrasies have been noted. Thus, while the formula for methane is given as $\mathrm{CH}_{4}$, that of monodeuteromethane is given as CD. Under the heading of the boiling point of methane at $760 \mathrm{~mm}$. of mercury pressure are to be found $\mathbf{1 7 0}$ entries for boiling points covering the pressure range 43,168$4.24 \mathrm{~mm}$. and fourteen entries for sublimation temperatures. The majority of these boiling points are arranged in descending order of pressure, but there are just enough entries out of order to break the sequence. The data on acetylene are misleading because, although this compound does not exist as a stable liquid at $760 \mathrm{~mm}$. pressure, since the triple point is at $962 \mathrm{~mm}$., yet four values for the boiling point at $760 \mathrm{~mm}$. are listed.

Vol. 1 was published in 1939 , and it is a pity that the opportunity was not taken in the present volume to include information on properties which have since been recognized as useful in establishing the identity and purity of hydrocarbon samples, for example, infra-red spectra, Raman spectra and cryoscopic constants. However, the cost of this volume is already so high that perhaps it is as well that the book was not expanded. Nevertheless, it contains much collected data, and there is no doubt that many librarians will be pleased to have this book to add to their set in this series.

E. F. G. Herington

\section{Paper Chromatography}

By Dr. Friedrich Cramer. Second revised and enlarged edition. (Translated by Leighton Richards.) Pp. xii $+124+4$ plates. (London: Macmillan and Co., Ltd. ; New York : St. Martin's Press, Inc., 1954.) 25s. net.

$\mathrm{T}$ is to be regretted that, in presenting this second, Ievised and enlarged edition of his book, the author has included so much subject-matter within such a limited space. The book, which is divided into two sections, is intended to provide a laboratory manual of paper chromatography. The first section deals sketchily and somewhat inaccurately with the history and theory of paper chromatography and then goes on to give a comprehensive and wellillustrated description of the various practical techniques. The newcomer to chromatography will find this portion of the book very useful.

The second section describes the application of paper chromatography to the separation of various groups of materials. The presentation of this portion of the book is unbalanced in that some applications are described in excessive detail whereas others receive only the briefest mention. A large number of useful tables and four hundred references, however, are included. That part of the book dealing with inorganic separations is so condensed and contains so many errors that it is better ignored. The book contains an annoyingly large number of mistranslations and spelling mistakes. $\quad$ R. A. WetLS 